DOI: $10.2478 /$ pof-2018-0021

VOLUME 10, ISSUE 2, 2018

ISSN: $2036-5438$

\title{
The Swiss Ständerat: a Model of Perfect Bicameralism
}

by

Eva Maria Belser*

Perspectives on Federalism, Vol. 10, issue 2, 2018 


\section{Abstract}

This paper presents the Swiss Ständerat as a model of perfect bicameralism. It looks at the constitutional design of the second Chamber, examines the evolution of the Ständerat and critically assesses its current functioning. The author claims that the Swiss Federal Assembly is still based on almost perfect bicameralism but that the second Chamber only very imperfectly represents the regions. Having highlighted the current role and justification of the second Chamber, the paper will raise the question whether the Ständerat fulfils other useful functions justifying its existence. Does the sheer fact of having two differently composed Chambers prevent capricious and precipitous decision-making? The paper then turns to alternative mechanisms of representing regions at the federal level, briefly looks at other mechanisms available to Cantons to make their voices heard in the capital and presents the House of the Cantons as an evolving third Chamber complementing the Ständerat.

\section{Key-words}

bicameralism, Ständerat, regional representation, Swiss federalism, intergovernmental relations 


\section{Introduction}

It would most likely come to a great surprise to most Swiss that the Council of States, the Ständerat (Conseil des Etats, Consiglio degli Stati), is linked to the notion of perfection in a conference on "Representing Regions, Challenging Bicameralism". The Swiss Council of States, in recent years, has been strongly criticized precisely for its lack of representing the regions, so strongly that few people still think of it as a model of perfection in any possible meaning of the term.

If today's Council of States no longer represents the regions, or does so rather ineffectively, what could it possibly be good for? Is the Council of States consequently not just an outdated Chamber favouring grand old parties and backward people at the expense of democracy and innovation? These are the kind of questions Swiss members of the second Chamber are more familiar with. The old institution today seems to be trapped in Abbé Sieyès famous epigram: "If the second Chamber dissents from the First, it is mischievous; if it agrees with it, it is superfluous."

This paper is not an attempt to solve the Council of States' identity crisis but will nevertheless defend its existence. If one understands the purpose of a bicameral system solely in representing the regions at the federal level and in safeguarding meaningful participation of the constituent units at the centre, one cannot help but conclude that the Swiss Council of States of today is, at least in part, a failure. Members of the Council of States sit and vote accordingly to party alliances and follow party programs which may or may not converge with the interests of the Cantons. It is only when the interest of one particular Canton or a geographic or linguistic region is at stake, that the members of the second Chamber overcome party politics and favour their Canton or region - but in such a case, the members of the National Council do just the same.

In this paper, I will first present the Swiss Council of States as a model of perfect bicameralism and lay out the main features of the Swiss institutional set-up. For this purpose, I will explore the origins of Swiss bicameralism as an institutional compromise to accommodate the conservatives, the composition of the Federal Assembly and the reform proposals relating to the Ständerat. I will then turn to the main question of the extent to which the Council of States takes the interests of the Cantons or regions into account and 
effectively fulfils its role of representing them. If we cannot help but conclude that the Swiss Council of States of today is, at least in part, failing in representing the Cantons, inevitably three further questions arise: Firstly, if the Council of States is not very effective in representing the Cantons and their interests in Bern, does it fulfil any other useful function to justify its existence? Is it fair to assume that, as generally acknowledged, bicameral law-making and bicameral decision-making beyond law-making as such improve the quality of decision-making in the Federal Assembly? Does the Swiss Council of States live up to the role of the chambre de reflexxion or Chamber of reason in which it likes to portray itself? Secondly and closely linked to that: Does the separation of powers within the legislative branch provide a useful safeguard against unfettered majoritarianism and prove itself a valuable counterbalance to the democratic majority rule? Lastly, if the Council of States is not in a position to forcefully represent cantonal interests at the federal level, who else is? In this part, I will present other mechanisms available to Cantons and I will in particular introduce the House of the Cantons as an evolving third Chamber.

\section{The Federal Compromise: Accommodating the Conservatives}

\subsection{Integrating Losing Forces into the New Federal System}

The emergence of Switzerland as a federal state in 1848 is closely linked to the Sonderbund War of November 1847, a short civil war opposing the confederated Cantons. The liberal, urban and dominantly protestant forces had obtained the majority in the Tagsatzung, the Federal Diet, and proposed a new, more centralized constitution for the Swiss Confederation. As a consequence, in 1845 seven conservative, rural and dominantly catholic Cantons formed a separate alliance, the Sonderbund, to jointly defend their interests and oppose centralisation. When Lucerne recalled the Jesuits to take charge of the education system, as a reaction to measures taken by the Federal Diet against the Roman Catholic Church, armed radicals invaded the Canton and caused turmoil. To prevent a spreading of the conflict, the liberal majority of the Federal Diet decided to dissolve the separate alliance, which was in violation of the Federal Treaty of 1815, and to militarily enforce its decision. The not very bloody war ended with the defeat of the Cantons united by the Sonderbund and paved the way for the revision of the Federal Treaty of 1815 (Pahud de Mortanges 2017: 205; Heger 1990: 63-64). 
The design of the new state, however, proved to remain controversial. The Constitution of 1848, transforming the Swiss Confederacy into a federal state, emerged as a strongly debated compromise between the liberal majority, advocating a unitary state and a powerful national government, and a conservative minority fighting for cantonal sovereignty and the preservation of a system of loose confederal cooperation (Jaag 1976: 10; Heger 1990: 65). In order to integrate the losing side in the civil war into the new political system, it was deemed necessary to preserve very far-reaching autonomy of the Cantons and to only centralise few matters of utmost importance to the rapidly industrialising state. Hence, the result of the constitution of 1848 was the creation of only a weak central state, and the preservation of strong cantonal independence (Linder and Vatter 2001: 96). While this vertical power-sharing structure allowed for the peaceful coexistence of communities - still not fully trusting each other, agreeing on the design of federal institutions posed a further challenge. Whereas the larger Cantons with thriving urban centres (the unionists) favoured parliamentary representation based on population size, the smaller rural Cantons (the federalists) insisted on upholding the intergovernmental system of the Federal Diet, characterised by unanimity requirements in most fields and by an equal number of delegates from each Canton acting on cantonal instructions (Pahud de Mortanges 2017: 208; Jaag 1976: 10; Marti 1990: 19). The conflict was rightly perceived as particularly menacing for the country, as the cleavage between large and small, urban and rural, catholic and protestant Cantons - and winners and losers in the war - largely coincided, and peace and stability was at risk (Linder and Vatter 2001: 96).

The way out of the controversy was a constitutional transplant: The introduction of the US model of bicameralism, combining a Chamber based on the equal representation of the constituent units with a Chamber based on population and giving both Chambers equal standing (Jaag 1976: 10; Heger 1990: 64-69). ${ }^{\mathrm{I}}$ Just like the US Senate, the Council of States mirrors the federal structure of the country. It is composed of 46 "representatives of the Cantons",II and stands for the principle "every Canton an equal vote". Just like the US House of Representatives, the National Council ensures a democratic representation of the people based on population size (Vatter 2014: 312). ${ }^{\text {III }}$ The losing side of the Sonderbund, fearing a total loss of sovereignty by means of majoritarian decision-making, had successfully insisted on constraining majoritarianism by creating a second Chamber based 
on equal representation and endowing it with equal prerogatives (Ebnöther 2017: 125; Bütikofer 2014: 21; Linder and Vatter 2001: 96).

From the beginning, the Swiss Council of States was seen less as a Chamber representing cantonal interests, than as a major concession to the catholic-conservative Cantons in curbing democratic majoritarian rule and enabling political cohesion (Heger 1990: 142). The counter-majoritarian elements introduced by the bicameral system and the requirement of a qualified majority for all constitutional changes ensured an appropriate representation of majority and minority views and conferred on the small cantons - when acting jointly - veto powers over centralizing forces (Ebnöther 2017: 122). The institutional compromise was not motivated by the need to protect linguistic minorities such as the French- or the Italian-speakers. This was not the salient cleavage of the time. There was no concern raised about the fact that German-speaking representatives were in a position to easily overrule the French- and Italian-speaking members of parliament; it seemed unlikely that the strongly opposing political camps within the German-speaking community would agree on crucial issues in the foreseeable future.

In the ratification process for the federal constitution, all the French-speaking, and all liberal Cantons opted in favour whereas five German-speaking, rural and conservative Cantons remained fiercely opposed to it (Marti 1990: 25). As unanimity would have been required to transform a confederacy into a federal state, the coming into being of the new state was severely flawed. The refusal of several small, rural, catholic, conservative and German-speaking Cantons to join the new state and the rejection of limitations of their sovereignty illustrates the depth of the cleavage and the necessity of considering the losing side's interests.

\subsection{Providing 46 Seats for 26 Cantons}

The Council of States is composed of 46 delegates of the Cantons. All Cantons are represented by two delegates but six by one only. ${ }^{\text {IV }}$ This inequality does not reflect differences in size or population but takes into account the fact that three Cantons went through a process of division before the establishment of the federal state. They were not allowed to double their voices accordingly and were referred to as half-cantons. ${ }^{\mathrm{V}}$ Ever since the 1999 constitutional revision, the six Cantons with only one delegate no longer carry the 
diminutive label, but still count as half in the Council of States and for proposals submitted to the vote of the People and Cantons.

In the past, it has repeatedly been requested that the six former half-cantons be upgraded to units with equal voice. In 1981, on the occasion of the establishment of the new Canton of Jura, the six half-cantons demanded by means of a parliamentary initiative to receive the status and prerogatives of fully-fledged Cantons. The reform proposal was, however, not pursued. The main reason for this was that all half-cantons are Germanspeaking and that the amendment would have increased the veto powers of Germanspeaking, mostly small and rural Cantons, at the expenses of the French-speaking west and the more populated urban Cantons. ${ }^{\text {VI }}$ The change would not only have affected the composition of the Council of States but also the qualified majority needed for constitutional amendments and for the accession to organisations of collective security, such as the NATO, or to supranational communities, such as the EU. ${ }^{\text {VII }}$ It did therefore not come as a surprise that the issue of upgrading the six former half-cantons to Cantons with full voice was again raised later in the context of the highly controversial debates of Switzerland's integration into the EU. While this debate is politically sensitive and characterized by deep cleavages between the French-speaking west and the Germanspeaking east of the country, it also illustrates the enduring urban-rural division. A close analysis of voting outcomes relating to the role of Switzerland in Europe and the world and the preferences for integration or a Swiss Sonderweg shows that most cities in the Germanspeaking part of the country vote in line with their French-speaking counterparts but are overruled by the rural parts of the Cantons. Increasing the votes of half-cantons would undoubtedly put strain on the century-old compromise.

When the Council of States was established, the counter-balancing effect of the Council of States and the qualified majority requirement was already quite significant: One representative of the Council of States from the Canton of Zurich represented 17 times as many people as his counterpart from the half-canton of Appenzell Innerrhoden. While the population size in the urban Cantons of Basel-Stadt, Geneva and Zurich has increased significantly over the last 170 years, it has remained almost static in rural Cantons (Sager and Vatter 2013). VIII Thus, the substantial voting power of a Swiss citizen residing in today's large and densely populated Cantons has become even weaker. The voting weight of a citizen of Zurich is nowadays about 44 times less than of a Swiss citizen living in one 
of the very small Cantons (Sager and Vatter 2013). If the proposal of upgrading halfcantons was accepted the sparsely populated and rural half-cantons would receive two seats in the Council, and the difference in representation would increase to 88 times.

Another reform proposal seeking to alter the current scheme of how seats are allocated in the Council of States goes in the opposite direction: It recommends the introduction of one or two extra seats for big cities, arguing that 70 per cent of the Swiss live in urban centres but only represent 30 per cent of the votes in the Council of States (Vatter 2014: 325). Proponents of the change also draw attention to the fact that the population size of the city of Zurich, for example, exceeds by far the total population size of the six smallest Cantons (Ebnöther 2017: 125). While these Cantons together hold eight seats in the Council of States, the city of Zurich and other important urban centres have none. The proposal aims therefore at giving an institutional voice to densely populated areas and at increasing the impact of hubs for political, social, economic, and cultural innovation. Until now, these and similar proposals failed in the preparatory committee stages of parliament. In 2010, National Councillor Hans Jürg-Fehr submitted a parliamentary initiative with the aim of allocating cities of more than 100,000 inhabitants one seat each. The idea subsequently also failed in the National Council with 113 to 41 votes. ${ }^{\text {IX }}$

Lastly, another reform proposal aimed at weighting the votes in proportion to population size. The idea was to allocate three seats to large, two seats to medium sized and just one seat to small Cantons (Linder and Vatter 2001: 118). The proposal would thereby solve the issue of the half-cantons by replacing the historic criteria by a demographic one and simultaneously take account of the since 1848 rapidly increasing de facto inequality of Cantons. The proposal has repeatedly been raised and discussed, most prominently in the context of the total revision of the Constitution in 1999, but has been shelved for the time being. As any change in the composition of the Council of States would require a constitutional amendment accepted by the majority of the Swiss population and the majority of the Cantons, proposals limiting the veto power of small (rural, Germanspeaking) Cantons are unlikely to be garner support in the near future as it is improbable that the small Cantons would volunteer to limit their own power. 


\section{The Two Chambers of the Federal Assembly: Unequal Partners with Equal Rights}

\subsection{Guaranteeing Symmetric Powers to the Council of States and the National Council}

The two parliamentary Chambers of the Swiss Federal Assembly, the National Council and the Council of States, are of equal standing (Ebnöther 2017: 121; Häfelin et al. 2016: N 1438). ${ }^{\mathrm{X}}$ The Swiss bicameral system is a model of 'perfect' symmetry in the sense that both Chambers enjoy exactly the same responsibilities, competences and powers (Ebnöther 2017: 121; Thurnherr 2015: Art. 148 Cst. No. 16; Bütikofer and Hug 2010: 178). Each Chamber can initiate constitutional amendments, laws and regulations as well as propose revisions of existing laws or regulation - there is no link to cantonal matters required. The same is true for all other competences and functions such as, inter alia, ratifying international treaties, giving budgetary authorisations, exercising political oversight over the actions of government and administration, validating popular initiatives and approving cantonal Constitutions (Häfelin et al. 2016: No. 1447). ${ }^{\text {I }}$

For each and every decision of Parliament, the approval by a majority of the votes casted in both Chambers is required. ${ }^{\mathrm{XI}}$ Deliberations by the National Council and the

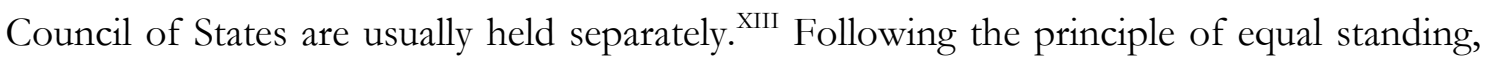
there is no priority rule in place as to which Chamber receives business for prior consideration (Thurnherr 2015: Art. 148 Cst. No. 18). ${ }^{\text {XIV }}$ After the Council which had received business for prior consideration has dealt and voted on it, the issue is passed on to the other Chamber for consideration. ${ }^{\mathrm{XV}}$ A proposal is normally not considered for the first time by both Chambers in the same session. ${ }^{\mathrm{XVI}}$ This delay in law-and decision-making is institutionally entrenched and designed to allow for further reflection, to prevent overhasty decision-making and to provide for a cooling-off period before the other Chamber starts working.

The joint proceedings of the National Council and the Council of States as the United Federal Assembly constitute a departure from the principle of separated deliberations. ${ }^{\text {XVII }}$ The most important power of the United Assembly is the appointment of the members of the Federal Council, the Federal Chancellor, the judges of the Federal Supreme Court and, in times of war, the Commander-in-Chief of the armed forces. ${ }^{\text {XVIII }}$ These joint proceedings 
not only depart from the principle of separated proceedings but also from the principle of equal footing. ${ }^{\text {IIX }}$ The sessions of the United Federal Assembly are held in the Assembly Hall of the National Council and operate under the presidency of the President of the National Council. ${ }^{\mathrm{Xx}}$ The particular parliamentary setting illustrates an underlying power shift: Since decisions made by the Federal Assembly are taken by the majority of those who vote, ${ }^{\mathrm{XXI}}$ and given the numerical superiority of the National Council, the votes of the delegates of the Cantons are diluted in the United Assembly. The National Council brings together more than $80 \%$ of the total number of votes to be cast and can therefore easily outvote the Council of States (Thurnherr 2015: Art. 157 Cst. No. 4; Häfelin et al. 2016: N 1507; Rhinow: 16). ${ }^{\mathrm{XXI}}$ The principle of equal standing between the two Chambers is therefore severely compromised when it comes to the elections mentioned above. From a federal point of view, the dilution of cantonal votes (and the lack of counter-majoritarian mechanisms) seems particularly problematic when federal counsellors and judges are appointed. Due to the operating of the United Assembly, both national bodies are more strongly legitimised by the representatives of the people then by those of the Cantons. The appointment process also affects the outcome. As there is a constitutional custom requiring that both federal bodies reflect the political composition of parliament ("magic formula"), the dilution of the votes of Council of States leads to the result that the federal executive and judiciary more accurately mirror the political landscape of the larger Chamber - at the expense of the smaller one which, as will be shown below, differs importantly in its political composition. In contrast to other federal states, the way of appointing Swiss federal judges does not provide for mechanisms guaranteeing that members of the Supreme Court enjoy double legitimacy (by the people and by the Cantons); this fact negatively affects the role of the court as a neutral arbiter capable of legitimately umpiring disputes between the two tiers of the state.

\subsection{Resolving Disputes between the Chambers}

If the decisions of the National Council and the Council of States differ following their initial consideration of the same proposal, the divergent decisions of each Council are referred to the other one for reconsideration. The draft law or proposal then goes back and forth between the Chambers until an agreement is reached between the two. ${ }^{\text {XxII }}$ In cases where both Chambers reach an agreement during the first three discussion rounds, a final 
vote on the proposal is held in each Council. If differences still remain, the business is submitted to a conciliation committee. ${ }^{\text {XxIV }}$ The latter proposes a compromise motion that is resubmitted to the two Chambers. If the compromise motion is not accepted by both Chambers, it is abandoned entirely. ${ }^{x \mathrm{x}}$ The National Council, even by qualified majority, has no means to overrule the Council of States.

Because its (smaller) size and flexibility, it would seem that the Council of States is the more influential of the two. A study carried out in 2008 by Linder and Schwarz, analysing the common procedure to eliminate differences between the two Chambers from 1996 to 2005, showed that the Council of States has indeed greater influence on law-making than its (larger) counterpart. The authors trace this back to the fact that given its smaller size, more homogeneous composition and the more conciliatory approach, the Council of States and its parliamentary committees are quicker in settling businesses and, therefore, receive more often business for prior consideration. As the Council which acts first, the Council of States thus gains greater influence through agenda-setting powers (Linder and Schwarz 2008: 32).

In contrast to other countries, the lack of success of the procedure used to reconcile differences between the Chambers is usually not perceived as a sign of an institutional trap, or a political blind alley. In most cases, the incapacity of the two Chambers to agree is rather seen as demonstrating the fact that the bill at stake did not strike the balance needed to make the deal acceptable to the representatives of the people and the delegates of the Cantons - and therefore should not pass. The willingness to accept institutional blockage and delay is closely linked to the direct-democratic rights of the Swiss people. As 50,000 citizens or any eight Cantons can request an optional referendum on federal acts, the necessity to find acceptable compromises and to negotiate moderate deals acceptable to most political actors involved is obvious to all. If this is not achievable in parliament, the bill is unlikely to succeed at the polls.

\section{The Councillors of State: Cantonal Delegates without Instructions}

\subsection{Appointing the Councillors of State}

The bicameral system of the Swiss Federal Assembly reflects the democratic principle of 'one person one vote' in one Chamber and the federalist principle of 'every Canton an 
equal vote' in the other (Linder and Vatter 2001: 98). The National Council is composed of 200 representatives who are directly elected by the people according to a system of proportional representation. ${ }^{\mathrm{x} v \mathrm{I}}$ Currently, the number of seats allocated to a Canton ranges from 35 representatives from the most populous Canton of Zurich to one (constitutionally guaranteed) $^{\mathrm{XXVII}}$ representative from each of the six least populous

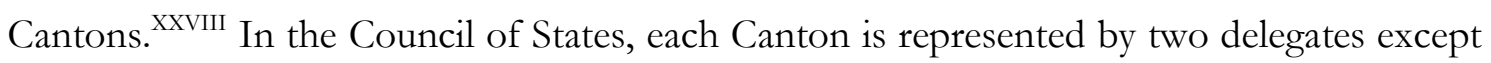
for the six half-cantons which only elect one representative (Biaggini 2007: Art. 150 Cst. No. 2). ${ }^{\text {XxIX }}$

As much as the two Chambers enjoy the same prerogatives, the way they are constituted differs. Whereas the election of the National Council is largely determined by federal law, the Cantons decide autonomously on the election of their representatives. ${ }^{\mathrm{xx}}$ When the first Council of States was elected in 1848, all Cantons provided for an indirect election through the parliaments of the Cantons (Heger 1990: 68). This way of proceeding ensured deep linkages between the cantonal legislatives and federal delegates. However, over time, Cantons introduced direct elections for members of the Council of States, thereby loosening these linkages. Nowadays all the representatives of the Cantons are directly elected by the people. The Canton of Bern was the last Canton to switch from an election by parliament to a popular election in 1977 (Sciarini 2013: 104; Marti 1990:36). Nothing in the federal constitution would prevent Cantons from returning to indirect elections - and to more closely link cantonal representation at the federal level to what a cantonal parliament wants - but no Canton is currently considering such a change.

While proportionate representation is compulsory for the election of the National Council since 1918, a system change which revolutionised the composition of parliament, all Cantons, except Neuchatel and Jura, have opted to continue to rely on a system of firstpast-the-post when electing members of the Council of States (Thurnherr 2015: Art. 150 Cst. No. 14). Other cantonal peculiarities still remain; the Cantons of Neuchâtel and Jura, for example, confer voting rights under certain circumstances to foreigners (Caroni 2013: 35-37). ${ }^{\mathrm{XxI}}$ The Canton of Glarus used its room for manoeuvre to introduce an age limit by stating that a representative of the Council of States cannot be older than 65. Some scholars, however, argue that such upper age limit infringes upon the prohibition of discrimination and is therefore unconstitutional (Federal Council's report 2004: 2136, 2137; Aubert 1995: 1013 No. 1285; Waldmann 2003: 475; Thurnherr 2015: Art. 150 Cst. No. 11). 
The Constitution does not provide for a specific legislative period. In practice, elections of the representatives of the Council of States are usually held at the same time as the elections for the National Council and the term of office is equally aligned (Häfelin et al. 2016: N 1501). Therefore, all Cantons have limited the term of office to four years (Thurnherr 2015: Art. 150 Cst. No. 12, 13).

Federal incompatibility rules prohibit that members of the Council of States are at the same time members of the National Council, the Federal Government or a Federal Court. $^{\text {Xxi }}$ The Cantons are bound by these restrictions enforcing personal power separation at the federal level. They are, however, entitled to go beyond them and introduce additional restrictions. Some Cantons have used this leeway and decided to offset power concentration vertically, too, by providing that none, only one or only two members of the collegial cantonal government can at the same time hold an office in the Federal Assembly (Thurnherr 2015: Art. 150 Cst. No. 15). ${ }^{\text {XxxIII }}$ Other Cantons do not provide for such rules and do not prevent deep personal linkages between the cantonal executive and the federal legislatives.

Historically, a number of members of cantonal governments simultaneously held a seat in the Federal Assembly and served as liaison between cantonal interests and federal decision-making (Bienlein 2000: 54). During the early decades of the Swiss federal state, a large number of members of cantonal governments also sat in the National Council or in the Council of States, giving the latter a flavour of the German Bundesrat. Heger (1990: 114) affirms that between 1848 and 1920 there have constantly been more than 10 members of the Council of States who were at the same time part of a cantonal government. The personal linkages between cantonal and federal tiers of government have declined over time, not only as a result of the introduction of direct elections, but also due to an increase of workload in all spheres of government. The Swiss Federal Assembly is still a militia parliament; most members of parliament have a professional life outside parliament. Today, however, parliament work, narrowly understood (sessions, meetings and committee work) takes up between $40-60 \%$ for members of the National Council, and $60-80 \%$ for members of the Council of States. The different workload results from committee work: The two Chambers have an almost equal number of committees, but the 200 members of the National Council can more easily distribute these among each other than the 46 members of the Council of States (Bütikofer 2013: 80). As a consequence of 
this, members of the cantonal government no longer sit in the Council of States and have, more recently, also disappeared from the lists of the National Council. Some members of the Federal Assembly still work as mayors of smaller municipalities and provide for personal interconnections between local executives and the federal legislative.

\subsection{Providing for a Free Mandate}

As much as the Cantons are free to shape the election of their representatives, they cannot go further than this: The federal Constitution prohibits them from instructing delegates $^{\text {XxxIv }}$ and guarantees free mandates to members of both Chambers alike. Just like members of the National Council (which are also elected by their cantonal constituencies), ${ }^{\mathrm{XxV}}$ members of the Council of States freely represent the population of their respective Cantons. While it is true that members of the Council of States regularly confer with their cantonal governments, any attempt to impact on free voting rights is prohibited (Ebnöther 2017: 125). In spite of their constitutional denomination as "delegates of the Cantons", members of the Council of States therefore do not cast their vote as delegates or ambassadors of the Canton, who would be bound to instructions of the cantonal government or parliament, but as politicians and members of the federal parliament (Aubert and Mahon 2003: Art. 149 Cst. No. 5; Auer 2016: 31). Thus, they are not accountable to the cantonal governments or the cantonal parliaments, ${ }^{\mathrm{xxvI}}$ and are representatives of the Cantons only by name (Häfelin et al. 2016: N 1492; Heger 1990: 114).

Given the limited role of the Cantons in the election process, and the lack of direct influence on their representatives, a reform proposal has been made for the conversion of the Council of States into a chamber of Cantons analogous to the German Bundesrat (Rhinow: 34). This model would not only profoundly affect the institutional set-up but practically also require a transition to the parliamentary system of government or other profound adjustments of the functioning of cantonal collegial governments. It seems to stand very little chance of being seriously considered.

\subsection{Voting in the Council of States}

Results from research on the extent to which the Council of States effectively takes cantonal interests into account are inconsistent. A study from the 1970s shows that two 
thirds of the members of the Council of States see themselves as delegates of the Cantons while only a quarter of the members of the National Council do so (Kerr 1981: 191). A similar outcome was reached in a study conducted in 2000 (Wiesli and Linder 2000; Vatter 2014: 325). Hence, subjectively at least, the members of the Council of States are conscious of their role as representatives of the Cantons and tend to pay greater attention to political issues sensitive to federalism.

However, closer examination of actual decision-making and voting behaviour reveals that neither of the Chambers effectively represents cantonal interests. Empirical investigations clearly show that the Council of States does not defend cantonal autonomy in a more significant way than the National Council (Vatter 2014: 326-328; Bienlein 2000: $60,61)$. Just like the members of the National Council, the members of the Council of States vote according to party affiliations in most situations. Moreover, there is ample evidence to support the argument that neither of the Chambers has been effective in preventing or slowing down ongoing centralising processes. Few of the Federal Council's legislative proposals have been altered by either of the Chambers in order to uphold or strengthen federal power sharing. It is true, however, that in the rare cases when modifications in favour of a more federalist solution have been made, they more often have originated in the Council of States (Vatter 2014: 327). Yet, in sum, it is safe to say that the Chamber does not fully fulfil its prime role of representing the cantonal interests (Vatter 2014: 326) - if such a role has ever been its prime function. This conclusion is further confirmed by recently issued federalism monitoring reports. According to these reports, regularly published by the Conference of cantonal governments (CCG), both Chambers are by and large centralizing forces but differ in degree. Of all initiatives taken by the National Council, 71\% showed centralising tendencies. This differs, but not greatly, from the Council of States where the figure amounts to $57 \%$. At the other end of the spectrum, only $5 \%$ of the initiatives launched by the first Chamber have taken a decentralising approach. In the Council of States this was the case in $18 \%$ of all initiatives taken (Monitoring Report 2017: 21).

The reasons for these findings lie mainly in the election process and the constitutional prohibition of instruction. Members of the Council of States do not represent the cantonal authorities but the population of the Canton. In order to be re-elected, delegates must show success at the federal level - which is more easily done by pointing to laws and 
policies initiated and supported than to effective prevention of centralising federal action. In addition, one has to keep in mind that it is erroneous to assume that all Cantons unequivocally oppose centralisation. This is especially not the case in the Swiss context of strong reliance on the principle of fiscal equivalence, where cantonal competencies weigh heavily on cantonal households regulated by debt brakes, and provide for financial incentives to accede to centralisation, especially for small and resource-poor Cantons.

When stating that the Council of States is rather ineffective in representing Cantons, we have to keep in mind that this was never really its mandate in the first place. The point that the Council of State is not a chamber of the regions is illustrated by the fact that, just like in the National Council, Councillors in the Council of States are seated according to their party affiliation - left and right party members sit together, not easterners and westerners or French- and German-speaking. The vocation of the Council of States has always been to provide for an overrepresentation of the population of small Cantons, the losing side in the Sonderbund war, and to serve as a counter-majoritarian mechanism. Ample empirical research illustrates that the Council of States still fulfils its essential function of providing for a federal counterweight in comparison to democratic majority rule (Vatter 2014: 327; Huber-Hotz 1991: 171). It is true that the denominational differences between Catholics and Protestants, salient in 1848, no longer threaten the political cohesion of the country. Yet, the smallest Cantons still have a blocking minority with 23 votes even though they only represent roughly a fifth of the Swiss population (Ebnöther 2017: 125; Linder and Vatter 2001: 100). Considering the massive demographic changes through urbanisation and strong but very uneven population growth, the counter-majoritarian effect has increased tremendously since 1848, and its legitimacy is being questioned. Today, it is not the inhabitants of the formerly catholic Sonderbundskantone that fear being outvoted, but the urban areas of the country (often voting in line with the French and Italian minorities), which feel dominated by the more conservative Cantons of central and eastern Switzerland. In theory, reforms often claimed to be of marginal importance to rural Cantons, such as immigration, socio-economic and political cooperation and international integration, can fail even though they are supported by $75 \%$ of the population. In practice, however, it is fair to say that such blockages challenging the institutional set-up rarely occur. Except for very few exceptions, failed constitutional reform projects have fallen short of majorities of both the people and the Cantons. 


\section{The Councillors of State: Actors of Compromise}

By establishing a separation of power within the federal legislative branch bicameralism originally served to counterbalance the dominant weight of the liberal Protestants and, more recently, of the densely populated urban Cantons. Like most other second Chambers, the Council of States also fulfils other functions. By delaying federal decision-making processes, it buys room for further reflection and offers the chance to improve law and policy-making. By implementing a procedure of institutional cooperation and mutual checks and balances, bicameralism has allegedly a conflict-diffusing effect and plays a stabilising role (Rhinow: 9).

A bicameral system with two Chambers of equal standing compels the two Councils to negotiate a consensus on political issues. As the majority in both Chambers can effectively exercise veto powers, both shape federal politics (Rhinow: 12). Numerous authors claim that the quality in parliamentary debates and in law-making is considerably enhanced through the common procedure to eliminate differences ${ }^{\mathrm{Xxx}}{ }^{\mathrm{xI}}$ when the two Chambers come up with different propositions on the same bill (Rhinow: 9; Linder and Vatter 2001: 98).

Even more importantly, bicameralism provides for two different fora of deliberation and thereby offers effective mechanisms for finding broad compromise, a particular characteristic of Swiss consensus democracy. The different forms of deliberations and negotiations in the National Council and in the Council of States are a product of the distinct features of the two Chambers; these are of more import than the differences in numbers. While proceedings are simultaneously interpreted into all three official languages in both the National Council and the United Federal Assembly, ${ }^{\text {XxxvIII }}$ there is, for instance, no simultaneous interpretation in the Council of States' proceedings. As a consequence, members of the National Council speak from the speaker's desk, use microphones and address an audience which, when present, wears headphones and waits for their turn to speak. Speaking time is restricted; speeches in the large Chamber are typically made for official protocol, the media and the respective constituencies and only very rarely lead to discussions. In contrast, members of the Council of States speak their mother tongue or the national language of their choice, mostly German and French, and rightly expect their 
audience to understand. ${ }^{\text {XxxIX }}$ Delegates of the Cantons speak from their seat to their colleagues, more often present, and real debates can evolve. While in the National Council there are sometimes up to 20 to 30 speakers in a row regarding one item of business in a Council debate (Neidhart 2005), it is best practice for a member of the Council of States to only speak up if they can introduce new arguments (Ebnöther 2017: 126). The openness for dialogue and the willingness to take new arguments into consideration is also highlighted by the fact that despite preliminary examinations by committees, deliberations in the Council of States are considered to be crucial with regard to decision-making, ${ }^{\mathrm{XL}}$ which is less the case in than National Council where opinions are typically made before discussions begin (Ebnöther 2017: 126; Marti 1990: 42).

For these and other reasons, the Council of States claims to be the chambre de reflexion, or Chamber of reason, significantly improving the quality of the decision-making and fulfilling the role of guaranteeing and implementing the federal Constitution, a particularly crucial function in a country with only limited judicial review of constitutionality (Rhinow: 8). The reason for the Council of States fulfilment, at least in part, of this role, stems from its election process. The proportionate voting used in the election of the National Council leads to a rather heterogeneous and fragmented Chamber. This large Chamber reacts very rapidly to changes in society and is very open to new trends as there are no legal thresholds in the election process. While in small Cantons with only one seat, candidates need to pass the de facto threshold of 50\% such is not the case in Cantons with lots of seats to fill where the natural quorum is very low. In a large canton with 30 seats, new, small and splinter parties can end up in parliament when they reach three percent of the votes. As a consequence, the National Council is polarised and vocal. Due to limited seats, this is not the case for the Council of States. The overarching political compositions in both Chambers therefore differ importantly. While the Swiss People's party, a right-wing party with a national-conservative program, is by far the strongest party in the National Council, it only holds five seats in the Council of States. Due to majority voting, delegates of the Cantons need very broad backing in their constituencies, and depend on the support of more than one party in order to be elected. Candidates of polarising parties find it hard to pass the post. The mode of election therefore proves paramount for the political composition of the Council of States in which the moderate Christian Democratic People's Party is still the strongest party. A party operating flexibly between the right- and left-wing 
parties is obviously more successful than its competitors with more pronounced party programs when it comes to proposing candidates capable of attracting voters beyond their own party basis (Ebnöther 2017: 125). The Council of States is thus composed of more moderate candidates with a greater capacity to debate, negotiate and compromise. The Chamber, home to politicians willing to reconcile and overcome differences in party programs, is therefore less likely to be caught in disputes resulting from partisan politics (Häfelin et al. 2016: 1492; Vatter, p. 319). The fact that the Council of States is characterised by some degree of homogeneity is best illustrated by the fact that between 2003 and 201180 per cent of the final votes in the Council of States were unanimous, while the National Council reached unanimity in less than 30 per cent of the cases (Vatter 2014: 319; Bütikofer 2014: 119 Fn. 134; Hug et al. 2011). The different election processes, however, also affect the age and gender balance. While the representation of younger people and of women is appallingly low in the National Council (roughly 30 per cent), average age is even higher in the Council of Sates and women still represent only roughly 20 per cent of the votes: The Chamber of reason is dominated by the minds of men turned grey.

The greater ease of members of the Council of States to agree is also linked to the fact that its members usually serve for longer periods and more intensively cooperate in committees. As each Council features almost the same number of committees, members of the Council of States typically sit in a number of working committees and intensively cooperate with their peers on a daily basis on various issues (Rhinow: 23). This creates scope for cross-party cooperation and supports a culture of consultation, dialogue and package deals. Cooperation is further facilitated by the fact that members of a given party in the Council of States enjoy more independence from their parliamentary group; they are not elected based on a party list but on candidate-centred elections (Rhinow: 23). Additionally, members of the Council of States have more political leverage given the small number of total members in the Council of States and the fact they are part of two or more parliamentary committees which automatically reinforces their political influence (Ebnöther 2017: 125, 136). Last but not least, the small number of Council members requires delegates to avoid conflicts and to cooperate more frequently and closely (Ebnöther 2017: 126). 
However, in recent times, party politics have also become more prevalent in the Council of States to the detriment of cantonal interests. Whilst it is still not very much appreciated when the representatives pursue party politics, it does, in reality, play an increasingly dominant role and representatives belonging to the same party coordinate their opinions more often than before. Non-partisan representatives have become rare. As in the National Council, different political alliances are formed in the different policy areas (Ebnöther 2017: 127). This is in line with a study showing that Council members of the same party in the two Chambers do not differ with regards to their political position (Bütikofer and Hug 2010: 188).

\section{The Representation of Cantons: Looking beyond Parliament}

\subsection{Making Cantonal Voices Heard}

Apart from the Council of States, there are other mechanisms which ensure that Cantons participate at the federal level. The Cantons and their institutions have a constitutionally enshrined right to participate in the federal decision-making process, in particular in the legislative process. Furthermore, they also have a constitutionally guaranteed right to be informed fully, and in good time, of the federal government's intention and to be consulted when their interests are affected, ${ }^{\mathrm{XLI}}$ including in the field of foreign policy decisions. ${ }^{\text {XLII }}$ This has opened a wide spectrum for cantonal governments and cantonal officials to impact on federal decision-making at the early stages and to make their voices heard throughout the decision-making processes, from agenda setting to implementation (Schweizer and Brunner 1998: 64, 65).

In addition, cantonal institutions also benefit from the general consultation process during which the Cantons, the political parties and interested groups are invited to express their views on important legislation, other projects of substantial impact and on significant international treaties. ${ }^{\text {XLIII }}$ Just like the right of Cantons to participate, the right to be consulted is a decisive power of Cantons and offers ample opportunities to initiate, amend or oppose federal bills. Most importantly, the consultation processes allow Cantons to use soft veto powers, to express dissatisfaction with federal projects and to attempt to stop them. Thanks to the hard power of requesting a referendum - which is available to 50,0000 
people or eight cantons - serious concerns expressed by at least a handful of Cantons are taken seriously and often lead to the amendment or renunciation of the project.

It is interesting to note that until now the Cantons have only once launched an optional referendum. ${ }^{\text {XLIV }}$ Back in 2003 they opposed a tax package which would have provided for revisions on the taxation of marriages, families and residential property as well as stamp duties. The Cantons successfully defended their cause in the 2004 vote when the tax reform was rejected by 65.9 per cent of the people (Ehrenzeller and Nobs 2014: Art. 141 Cst. No. 11; Sciarini 2013: 104). ${ }^{X L V}$ While cantonal referendums are rare, their threat is always clearly present and usually sufficient for the federal tier to take cantonal concerns into account (Sager and Vatter 2013). The fear of cantonal opposition reveals its effect at the stage of the preliminary proceedings and compels federal authorities to give great importance to cantonal views in order to develop a proposal capable of reaching a consensus (Ehrenzeller and Nobs 2014: Art. 141 Cst. No. 12). ${ }^{\text {XLVI }}$

\subsection{Requiring a Double Majority}

Similar to the role of the Council of States, the requirement of the double majority for constitutional amendments operates in a way that restrains the democratic principle of the majority in favour of federal considerations. In doing so, it continues to effectively fulfil its historical core function of protecting the less populous and more rural conservative Cantons from being outvoted by the population of large ones. However, this mechanism has been questioned against the backdrop of demographic changes and the legitimacy of a blocking cantonal vote in the light of an overall approving people's will (Kley 2014: Art. 142 Cst. No. 10). While some authors claim that the counter-majoritarian effect of the qualified majority goes too far nowadays, others no longer see any reason to protect the populations of small Cantons against those of urban centres. In theory, the smallest blocking minority representing 51 per cent of the votes in the smallest Cantons can be reached with only 9 per cent of the total Swiss population today (Linder and Vatter 2001: 98).

One must keep in mind, however, that disagreements between the people and the Cantons are extremely rare. Only nine out of several hundred proposals to amend the federal constitution were approved by the people but failed because of a lack of agreement from the Cantons. Nevertheless, the fact that seven out of these nine cases occurred in the 
past 50 years highlights the growing significance that the requirement for the double majority has acquired in recent times (Linder and Vatter 2001: 98). In 1994, for instance, a constitutional amendment in favour of a simplified naturalisation procedure for young immigrants was rejected by less than 18 per cent of the votes - and failed (Sager and Vatter 2013). ${ }^{\text {XLVII }}$ While events such as these take a toll on democratic decision-making, it is still important to keep in mind that the requirement of the double majority was established to protect cantonal autonomy and that all nine proposals rejected by a majority of the Cantons were indeed related to an expansion of federal competences (Kley 2014: Art. 142 Cst. No. 10; Aubert and Mahon 2003: Art. 142 Cst. No. 6; Biaggini, 2007, Art. 142 Cst. No. 13). In the case of the naturalisation of foreign nationals, for example, legislative powers remain to a considerable extent in the realm of the Cantons, whereas the federal state may only enact minimum requirements in this area (Achermann and von Rütte 2015: Art. 38 No. 33). ${ }^{\text {XLVIII }}$

The question remains, however, whether the Cantons on the losing side in of the Sonderbund war are still in need of the protection provided by the double-majority rule. First, their political integration at the federal level is no longer a current need. Second, political cohesion is today more often put under stress by disagreements between urban centres with large populations and the French- or Italian-speaking Cantons which are considered to be underrepresented in the current system. In 2002, for example, Switzerland voted in favour of joining the United Nations Organization (UNO) with 54.6 per cent to 45.4 per cent of the votes of the people. The vote of the Cantons was not as clear though. A blocking minority was only missed by one cantonal vote, with 12 Cantons in favour of accession and 11 Cantons against. It would have been difficult to justify why a smaller, rural and German-speaking minority might have a bigger say and can overrule an urban and French-speaking democratic majority which is usually more inclined to pursue an integrationist foreign policy (Aubert and Mahon 2003: Art. 142 Cst. No. 6 Fn. 5; Linder and Vatter 2001: 98, 99). Neither the urban regions, which are characterised by a politically more progressive stance, nor the language minorities, are protected by the countermajoritarian design of the vote of the Cantons (Linder and Vatter 2001: 98).

Even though the double-majority fulfils a counter-majoritarian role, it is not designed in such a way as to confer veto powers on individual Cantons. Unanimity is not a requirement, even for the most fundamental changes, and it is obvious that the Swiss 
Confederation is confederal by name only and not by fact. This is best illustrated by the point that the establishment of the first federal Constitution in 1848 and both total revisions of 1874 and 1999 were rejected by the five small, predominantly rural and catholic Cantons of Uri, Schwyz, Unterwalden, Obwalden and Appenzell Innerrhoden and nevertheless entered into force (Kley 2011).

\subsection{Observing the Making of a Third Chamber}

The Conference of cantonal governments was founded in the wake of the referendum on Swiss membership in the European Economic Area in 1992, where 50.3 per cent of the public vote and 19 Cantons rejected the treaty. Its foundation was related to the growing awareness of a loss of cantonal autonomy, due to an institutional trend towards centralisation, and against the backdrop of foreign policy gaining an increasingly important dimension for domestic politics (Sciarini 2013: 103; Kolarov 2015: 232). In order to ensure participation at the federal level and retain cantonal influence, closer cooperation among the Cantons was deemed necessary (Kolarov 2015: 232). The Conference of cantonal governments is composed of the 26 cantonal governments and therefore directly represents their interests. ${ }^{\text {XIIX }}$ Thus, the Conference serves as a forum for promoting cooperation between Cantons on matters falling within their competence, or concerning federal competences having implications for the Cantons. In doing so, it effectively coordinates the Cantons' formation of opinion and ensures the representation of their interests towards the Federal Government (Kolarov 2015: 222).

The emergence of the Conference of cantonal governments can also be understood as an attempt to step in and assert cantonal interests more actively at the federal level precisely because of the lack of direct representation by the Council of States and the prohibition of voting instructions by cantonal authorities (Vatter 2006: 41; Sciarini 2013: 104).

The office of the Conference is located in the House of Cantons in the city of Berne, situated in the immediate vicinity of the Federal Palace where the Federal Assembly and the Federal Council are located. Apart from the Conference of cantonal governments (CCG) the building hosts several inter-cantonal governmental and directorial boards and other political institutions related to cantonal politics. The House of Cantons therefore serves as a crucial hub in coordinating and promoting cantonal interests at the federal level. 
The way in which the conferences exercise their influence is, in part, informal. There is hardly any new legislation passed to the two Councils without prior consultation of the Cantons or the CCG. The Cantons still hold a big share of public spending and most federal policies are executed on cantonal level (Ladner: 2014). Just like in German federalism, federal competences are, as a rule, limited to law-making; implementation is the task of the constituent units. This gives Cantons significant political leverage and latitude to pursue their own interests. As the federal tier relies on the Cantons for the execution of its policies, it has a strong interest in working with cantonal governments in approving plans and bills. The more the Cantons role is reduced to that of an enforcer of federal laws and regulations, the more important it becomes for Cantons to impact on federal policy making and to compensate centralisation by strengthened participation (Biaggini 2007: Art. 5a Cst. No. 9). This evolution from cantonal independence to cantonal participation is among the reasons why the House of Cantons is evolving into an informal German Bundesrat-style third Chamber.

As mentioned above, it is important to keep in mind that the crucial soft power of cantonal governments is complemented by hard power: The demand for an optional referendum. It is generally acknowledged that the CCG played an active and leading role in the referendum campaign of 2003 against the tax reform and the successful outcome underlined the high political significance of the CCG (Ehrenzeller and Nobs 2014: Art. 141 Cst. No. 11; Sciarini 2013: 103). The tax reform proposal also made it apparent that the Council of States had not represented the interests of the Cantons, as it had been the Council of States itself which had proposed the introduction of new provisions on the taxation of residential property in the tax package - even though this was the issue which upset the Cantons the most (Sciarini 2013: 104). Officially upgrading the CCG to a Chamber of the Cantons would, however, create controversy. Federalism is not solely limited to the representation of the cantonal governments, but requires the representation of the entire Canton, including the parliaments and peoples. There are some justified concerns about paying a price for further impact in the capital in terms of transparency, equality and democracy. 


\section{Conclusions}

In granting equal rights and duties to both Chambers of the federal parliament the Swiss bicameral system does not guarantee the representation of cantonal interests at the national level. As the so-called Swiss Confederation is, in realty, a federation, any Canton's delegates can easily be overruled. There are no qualified majority requirements, even for issues of the most crucial relevance for one or several Cantons. As a consequence, objections submitted by the Italian-speaking southern Canton of Ticino or the Frenchspeaking Cantons of the country's western region can be outvoted by the German-speaking majority of delegates. The role of the Council of States in protecting the views and concerns of linguistic minorities is therefore severely limited. In addition to majority decision-making, the direct election of the members of the Council of States within their cantonal constituencies and the constitutional prohibition of instruction further limit the effectiveness of the representation of cantonal interests - at least as far as they are expressed by the views of cantonal parliaments and governments.

The fact that the Council of States fails in defending cantonal autonomy and other cantonal interests, despite its equal rights and privileges to those of the National Council, and ensuing veto powers, does not come as a surprise. Historically, the Council of States served a different function: It was designed as an institutional mechanism to politically integrate Cantons unwilling to join the new federal state and to guarantee their overrepresentation. This counter-majoritarian role of the second Chamber is nowadays still the dominant one: The Ständerat serves as an institutional guarantee to the populations of smaller Cantons and prevents them from ending up as permanent losers of national decision-making. It functions as an institutional device protecting the populations of rural Cantons from being dominated by the ever-growing urban centres, more and more distinctly underrepresented in the Council of States. While some voices raise the concern that bicameralism negatively affects democracy and excessively disadvantages highly populated Cantons, others claim that the institutional compromise continues to serve the political cohesion of the country and to effectively deal with the salient rural-urban divide.

As a counter-majoritarian Chamber, the Council of States and its specific features undoubtedly strongly contribute to the consensual model of democracy specific to Switzerland (Rhinow, p. 36). The Swiss system strongly relies on compromise and is 
fundamentally opposed to the concept of "winner-takes-all"; the Council of States plays a decisive role in entrenching this governance model.

Taken into consideration the functioning of the Council of States and the fact that its members mostly act according to party affiliation, the cantonal institutions depend on alternative mechanisms to represent their interests at the federal level. On the one hand, they rely on the qualified majority required for constitutional amendments and on the possibility of requesting a referendum to oppose federal statutes and international treaties. The constitutional right of any group of eight Cantons to demand a vote on any federal statute serves as an effective preventive device requiring law-making actors to take cantonal concerns seriously. Cantonal governments therefore play a decisive role in the preparation of federal bills and increasingly often participate in working groups and preparatory committees. In some fields, the loss of cantonal autonomy is therefore rather effectively compensated by increased participation in the capital.

On the other hand, the Cantons have increased their influence on federal decisionmaking by strengthening horizontal intergovernmental relations. The Conference of cantonal governments and all the other cantonal conferences based in the House of Cantons in Bern have become crucial actors in Swiss federalism. By harmonising cantonal actions in matters of cantonal competence, they have found persuasive ways of preventing or limiting federal interference. Just as importantly, these intergovernmental institutions have evolved into actors decisively impacting on federal policy- and law-making by coordinating the views of Cantons in consultation and other participatory processes. In this field, the institutions united in the House of the Cantons, most of all the Conference of cantonal governments, are evolving into a German-style Bundesrat which has an important say in all matters of interest to the Cantons. De facto, federal statues and international treaties, requiring cantonal implementation, are no longer adopted without the approval of the Cantons. Informally, the Swiss system therefore is evolving into a new form of tricameralism whereby the Council of States serves political moderation, helps consensus finding and limits majoritarian decision-making, while the House of Cantons powerfully represents cantonal interests. Such an evolution matches the mixed form of Swiss federalism in which the Cantons on the one hand enjoy distinct competencies and legislative powers (dual federalism), and on the other hand are also mandated to implement federal decisions and laws (integrated federalism). It is therefore reasonable to expect 
further strengthening of intergovernmental decision-making combining horizontal and vertical cooperation. The main challenges resulting from this evolution are related to the rule of law and democracy: The future legitimacy of this complex system will depend on its capacity to guarantee transparency and clear responsibilities, to prevent scapegoating and excessive power-shifts to governments and administrations, thus reducing cantonal parliaments to institutions which merely rubber stamp decisions that have already been taken elsewhere.

\footnotetext{
* I am very grateful to MLaw Annkathrin Schüssler for her valuable help in the preparation of this text and to MLaw Simon Mazidi for his great assistance during the research process and in the editorial revision of the text.

I The constitutional transfer was almost a "copy and paste" process to the extent that Switzerland in the early years was often referred to as being the twin republic of the USA - a non-identical twin of course, given the differences in size and character.

II Art. 150 para. 1 of the Swiss Constitution.

III Art. 149 of the Swiss Constitution.

IV Art. 150 para. 2 of the Swiss Constitution.

$\mathrm{V}$ The same treatment was not applied when the French-speaking and catholic Jura population voted to separate from the mostly German-speaking and protestant Canton of Bern in 1977 as it later received two seats in the Council of States.
}

VI See the interpellation by National Councillor David Zuberbühler, available at https://www.parlament.ch/de/ratsbetrieb/suche-curia-vista/geschaeft?AffairId=20161055 (last access 27th April 2018).

VII Art. 140 para. 1 of the Swiss Constitution.

VIII Sager and Vatter estimate that the population size in Basel City has risen by a factor of seven, in Geneva by a factor of six and in Zurich by a factor of five. In the same period of time the population size in Appenzell Innerrhoden remained almost exactly the same while in Appenzell Ausserrhoden it only increased by a factor of 1.2.

IX See the parliamentary initiative put forward by National Councillor Fehr Hans-Jürg, https://www.parlament.ch/de/ratsbetrieb/amtliches-bulletin/amtliches-bulletin-die-verhandlungen?Su bjectId=21012 (last access 27th April 2018).

$\mathrm{x}$ Art. 148 para. 2 of the Swiss Constitution.

XI Art. 163-173 of the Swiss Constitution.

XII Art. 156 para. 2 of the Swiss Constitution; Art. 83 para. 1 of the Federal Act on the Federal Assembly.

XIII Art. 156 para. 1 of the Swiss Constitution.

XIV Art. 84 para. 1 of the Federal Act on the Federal Assembly.

xv Art. 86 para. 1 of the Federal Act on the Federal Assembly.

XVI Art. 85 para. 1 of the Federal Act on the Federal Assembly.

XVII Art. 156 para. 1 of the Swiss Constitution.

XVIII Art. 168 para. 1 of the Swiss Constitution.

XIX Art. 148 para. 2 of the Swiss Constitution.

xx Art. 157 para. 1 of the Swiss Constitution and Art. 39 para. 2 of the Federal Act on the Federal Assembly. xxI Art. 159 para. 2 of the Swiss Constitution.

XXII Moreover, the meeting is chaired by the presidency of the President of the National Council who must abstain from voting unless the taking of votes by the Federal Assembly results in a tie when the President has the casting vote, see Art. 80 para. 1 of the Federal Act on the Federal Assembly.

XXIII Art. 89 para. 1 of the Federal Act on the Federal Assembly.

xxiv Art. 91 para. 1 of the Federal Act on the Federal Assembly.

xxv Art. 92 and Art. 93 of the Federal Act on the Federal Assembly.

xxvI Art. 149 para. 1 and 2 of the Swiss Constitution.

xxvII Art. 149 para. 4 second sentence of the Swiss Constitution. 
xxvIII The six least populous Cantons are Uri, Obwalden, Nidwalden, Glarus, Appenzell Innerrhoden and Appenzell Ausserrhoden.

XXIX The six half-cantons are the Cantons of Obwalden, Nidwalden, Basel-Stadt, Basel-Landschaft, Appenzell Ausserrhoden and Appenzell Innerrhoden.

xxx Art. 150 para. 3 of the Swiss Constitution.

xxxi Art. 37 of the Cantonal Constitution of Neuchâtel and Art. 73 of the Cantonal Constitution of Jura.

XxxII Art. 144 para. 1 of the Swiss Constitution.

xxxiII See for example Art. 22 para. 4 of the Cantonal Constitution of Grison or Art. 63 para. 3 of the Cantonal Constitution Zurich.

xxxiv Art. 161 para. 1 of the Swiss Constitution.

xxxv Art. 149 para. 2 of the Swiss Constitution.

xxxvi Art. 161 para. 1 of the Swiss Constitution.

xxxviI Art. 89 para. 1 of the Federal Act on the Federal Assembly.

xxxviII Art. 37 para. 2 of the Standing Orders of the National Council.

Xxxix In 1991, legislative amendments provided for simultaneous translations for parliamentary committee meetings - as a rule for committees of the National Council and on request for committees of the Council of States. With regards to the Council of States committee's deliberations the possibility was removed from the standing orders in 2003 again as it had not been evoked a single time through this entire time; see parliamentary initiative regarding the total revision of the bylaws of the Council of State, BBL 20033508 : 3519 available at https://www.admin.ch/opc/de/federal-gazette/2003/3508.pdf (last access 27th April 2018).

XL See press release issued by the Secretariat of the Office of the Council of States, 'Medienmitteilung vom 27. September 2016, Bekräftigung und Präzisierung der Grundsätze zum Ratsbetrieb' available at, https://www.parlament.ch/press-releases/Pages/mm-bue-s-2016-09-27.aspx (last access 26th April 2018).

XLI Art. 45 of the Swiss Constitution.

XLII Art. 55 of the Swiss Constitution.

XLIII Art. 147 of the Swiss Constitution.

XLIV See BBl 20034498 for the draft Federal Act available at https://www.admin.ch/opc/de/federalgazette/2003/4498.pdf and BBl 20037056 for the holding of the referendum available at https://www.admin.ch/opc/de/federal-gazette/2003/7056.pdf (last access 27th April 2018).

XLV See for the result, BBl 20043943 available at https://www.admin.ch/opc/de/federalgazette/2004/3943.pdf (last access 27th April 2018).

XLVI Similar Epiney and Diezig 2015: Art. 141 Cst. N 14, they, however, give less weight to the cantonal referendum in emphasizing that is has been only used once and that the short time of request provided presents a considerable obstacle of its use in practice.

XLVII The proposal was, however, approved by 52.8 per cent of the population.

XLVIII Art. 38 para. 2 of the Swiss Constitution.

XuIx Art. 2 para. 1 of the Agreement on the Conference of Cantonal Governments of 8 October 1993.

\section{References}

- Albert Richard, 2013, 'The Expressive Function of Constitutional Amendment Rules', McGill Law Journal, LIX(2): 225-281.

- Albert Richard, 2014, 'The Structure of Constitutional Amendment Rules', Wake Forest Law Review, XLIX(4): 913-975.

- Achermann Alberto and von Rütte Barbara, 2015, 'Kommentar zu Art. 37, 38', in Waldmann et al. (eds), Basler Kommentar, Bundesverfassung, Helbing Lichtenhahn, Basel.

- Aubert Jean-François and Mahon Pascal (eds), 2003, Petit commentaire de la Constitution fédérale de la Confédération suisse du 18 avril 1999, Schulthess, Zurich-Basel-Geneva.

- Aubert Jean-François, 1995, Bundesstaatsrecht der Schweiæ, Band II, Helbling Lichtenhahn, BaselFrankfurt am Main.

- $\quad$ Auer Andreas, 2016, Staatsrecht der schweizerischen Kantone, Stämpfli Verlag, Bern. 
- $\quad$ Bernhard Ehrenzeller and Nobs Roger, 2014, 'St. Galler Kommentar zu Art. 141 BV, Rz. 5-22', in Ehrenzeller Bernhard et al. (eds), Die schweizerische Bundesverfassung, St. Galler Kommentar, Dike and Schulthess, Zurich-Basel-Geneva-St. Gallen.

- Biaggini Giovanni, 2007, BV Kommentar, Bundesverfassung der Schweizerischen Eidgenossenschaft und Auszüge aus der EMRK, den UNO-Pakten sowie dem BGG, Orell Füssli, Zurich.

- Bienlein Martin, 2000, Die Vertretung der Kantone im Ständerat, gemessen an parlamentarischen Vorstössen, Institut für Politikwissenschaft, Bern.

- Bütikofer Sarah, 2014, 'Das Schweizer Parlament, Eine Institution auf dem Pfad der Moderne', in Helms Ludger et al. (eds), Politics and Governance in the Smaller European Democracies, Vol. 9, Nomos, BadenBaden.

- Bütikofer Sarah and Hug Simon, 2010, 'The Swiss Upper House: 'Chambre de Réflexion' or Conservative Renegades?', The Journal of Legislative Studies, XVI(2): 176-194.

- Caroni Martina, 2013, 'Herausforderungen Demokratie', Zeitschrift für Schweizerisches Recht, CXXXII(II): 9-93.

- ch Stiftung für eidgenössische Zusammenarbeit (ed), 2017, Monitoringbericht Föderalismus 2014-2016, Bern.

- $\quad$ Ebnöther Christoph, 2017, Leitfaden durch das politische System der Schweiz, Orell Füssli, Zurich.

- Epiney Astrid and Diezig Stefan, 2015, 'Kommentar zu Art. 138-142, 192-194', in Waldmann et al. (eds), Basler Kommentar, Bundesverfassung, Helbing Lichtenhahn, Basel.

- Federal Council's report on age limits, 2004, in Bundesblatt Nr. 17 vom 4. Mai 2004, available at https://www.admin.ch/opc/de/federal-gazette/2004/2113.pdf (last access 27th April 2018).

- Häfelin Ulrich, Haller Walter, Keller Helen and Thurnherr Daniela, 2016, Schweizerisches Bundesstaatsrecht, Schulthess, Zurich-Basel-Geneva.

- Heger Matthias, 1990, Deutscher Bundesrat und Schweizer Ständerat, Gedanken zu ibrer Entstehung, ibrem aktuellen Erscheinungsbild und ihrer Rechtfertigung, Duncker u. Humblot, Berlin.

- Huber-Hotz Annemarie, 'Das Zweikammersystem - Anspruch und Wirklichkeit', in Parlamentsdienste (ed), Das Parlament - «Oberste Gewalt des Bundes»? Festschrift der Bundesversammlung zur 700-JahrFeier der Eidgenossenschaft, Haupt, Bern-Stuttgart.

- Hug Simon, Bütikofer Sarah and Martin Danielle, 2011, 'Koalitionen im Stöckli', Neue Zürcher Zeitung vom 13.10.2011, available at https://www.nzz.ch/koalitionen im stoeckli-1.12964320 (last access 27th April 2018).

- Jaag Tobias, 1976, Die Zweite Kammer im Bundesstaat, Funktion und Stellung des schweizerischen Ständerates, des deutschen Bundesrates und des amerikanischen Senats, Schulthess, Zurich.

- $\quad$ Kerr Henry H., 1981, Parlament et société en Suisse, Editions Georgi, Saint-Saphorin.

- Kley Andreas, 2011, 'Bundesverfassung (BV)', in Historisches Lexikon der Schweiz. (HLS) 03.05.2011, available at http://www.hls-dhs-dss.ch/textes/d/D9811.php (last access 27th April 2018).

- $\quad$ Kley Andreas, 2014, 'St. Galler Kommentar zu Art. 142 BV', in Ehrenzeller Bernhard et al. (eds), Die schweizerische Bundesverfassung, St. Galler Kommentar, Dike and Schulthess, Zurich-Basel-Geneva-St. Gallen.

- Kolarov Ana, 'Der koordinierte Pluralismus in der schweizerischen Aussenpolitik, Die völkerrechtliche Vertragsschlussfähigkeit der schweizerischen Kantone in verfassungsgeschichtlicher Perspektive', Zürcher Studien zum öffentlichen Recht, Vol. 226, Schulthess, Zurich-Basel-Geneva.

- Ladner Andreas, 2014, 'The Swiss Federal Assembly: Limited power but strong members of parliament', in The Political Studies Association, 8 July 2014, available at https://www.psa.ac.uk/psacommunities/specialist-groups/parliaments-and-legislatures/blog/swiss-federal-assembly-limited (last access 27th April 2018).

- Linder Wolf and Schwarz Daniel, 2008, Das Verbältnis von National- und Ständerat im Differenz̧bereinigungsverfahren 1996-2005, Eine Analyse von Einflusspotenzial und Koalitionsverhalten, Studie im Auftrag der Parlamentsdienste der Schweizerischen Bundesversammlung, IPW Universität, Bern.

- $\quad$ Linder Wolf and Vatter Adrian, 2001, 'Institutions and Outcomes of Swiss Federalism: The Role of Cantons in Swiss Politics', West European Politics, XXIV(2): 95-122.

- Marti Urs, 1990, Zwei Kammern - ein Parlament, Ursprung und Funktion des schweizerischen Zweikammersystems, Huber, Frauenfeld. 
- $\quad$ Neidhart Leonhard, 2005, 'Der diskrete Charme des Ständerats', Neue Zürcher Zeitung vom 18.12.2005, available at https://www.nzz.ch/articleDF86J-1.191682 (last access 26th April 2018).

- $\quad$ Pahud de Mortanges René, 2017, Schweizerische Rechtsgeschichte, Ein Grundriss, Dike, Zurich-St. Gallen.

- Rhinow René, 'Bundesrat und Ständerat, Die föderalistischen Kammern Deutschlands, Österreichs und der Schweiz', available at http://wp.rene-rhinow.ch/wp-content/uploads/2017/03/3-c-8-Bundesratund-Sta \%CC\%88nderat.-zur-Funktion-zweiter-Kammern-2007.pdf (last access 25th April 2018).

- Sager Fritz and Vatter Adrian, 2013, 'Föderalismus contra Demokratie', Neue Zürcher Zeitung vom 06.03.2013, available at https://www.nzz.ch/schweiz/foederalismus-contra-demokratie-1.18041403 (last access 26th April 2018).

- Schweizer Rainer J. and Brunner Stephan C., 1998, Die Mitwirkung der Bundesländer an EU-Vorhaben in der Bundesrepublik Deutschland und Österreich, Ein Modell für die Mitwirkung der Kantone in der Aussenpolitik, Stämpfli Verlag and Schulthess, Bern-Zürich.

- Sciarini Pascal, 2013, 'Le rôle de la CdC dans la représentation des intérêts des cantons face à la Confédération', in Hänni Peter et al. (eds), Publikationen des Instituts für Föderalismus Vol. 4, 20 Jahre KdK - Les 20 ans de la $C d C-20$ anni delle $C d C-20$ onns $C d C$, Stämpfli Verlag, Bern, 103-105.

- Thurnherr Daniela, 2015, 'Kommentar zu Art. 148-162', in Waldmann et al. (eds), Basler Kommentar, Bundesverfassung, Helbing Lichtenhahn, Basel.

- Vatter Adrian, 2006, 'Der Ständerat: Wirkungsweise und Reformansätze', in Vatter Adrian (ed), Föderalismusreform, Wirkungsweise und Reformansätze föderativer Institutionen in der Schweiz, NZZ Libro, Zürich, 4072.

- Vatter Adrian, 2014, Das politische System der Schweiz, Nomos, Baden-Baden.

- Waldmann Bernhard, 2003, 'Altersgrenzen im Recht', in Hänni Peter (ed), Mensch und Staat, Festgabe der Rechtswissenschaftlichen Fakultät der Universität Freiburg für Thomas Fleiner zum 65. Geburtstag, Universitätsverlag, Freiburg, 470-483.

- Wiesli Reto and Linder Wolf, 2000, Repräsentation, Artikulation und Durchsetzung kantonaler Interessen in National- und Ständerat, Studie im Auftrag der Eidgenössischen Parlamentsdienste, Institut für Politikwissenschaften, Bern. 